\title{
Measuring Increases In Horizontal Equity In The Absence Of Certain Itemized Deductions And Phase Outs
}

Susan Rhame, University of Dallas, USA

Robert Walsh, University of Dallas, USA

\begin{abstract}
A topic that generates extensive debate and concern is the perception of fairness in the US tax system. This "fairness" is often defined as vertical equity - taxpayers with different amount of income pay different amounts of taxes, and horizontal equity - taxpayers with the similar income pay the same level of taxes. Since the late 1980s, the number of phase outs in the United States individual income tax system has increased substantially. The effect of these phase outs has, in some cases, increased certain societal-valued activities, while at the same time discouraged reduction in taxes to others who are viewed as upper-income. On the other hand, some of these phase outs, and the ability to use them, may simply be a matter of luck or timing, or both. When this is the case, the tax liability of two people with very similar incomes may become very different, thus decreasing horizontal equity. This study begins by examining changes in horizontal equity (as measured by the coefficient of variation) when deleting two individual tax deductions. Using the Internal Revenue Service Tax File database for roughly 60,000 married filing joint returns, we examined the sensitivity of equity measures to two "artificial" changes in the tax laws - the disallowance of the mortgage interest deduction and the charitable contribution deduction. Not surprising, we find the disallowance of either or both deductions increases horizontal equity. Additionally, in the absence of phase outs (using the 1989 IRS tax file), we prove that as income groups become more numerous (and hence narrow bands of income), horizontal equity increases as well. This outcome is at odds with prior tax equity studies that make the assumption that increasing or decreasing the number of equal circumstance groups (taxpayers with similar income) will have no substantive effect on the outcome of horizontal equity measures. It also shows that increasing phase outs, when only benefits some in even very narrow income groups, has the effect of decreasing horizontal equity. This study has important implications in two respects. First, from a methodological standpoint, prior studies should have strengthened their assumption on the number of equal income groups used. Second, from a public policy perspective, continuing to increase the number of phase outs within the tax system further distorts horizontal equity, thus undermining the fairness and equity perception of the tax system.
\end{abstract}

Keywords: taxation, horizontal equity, mortgage interest deduction, charitable contribution deduction

\section{INTRODUCTION}

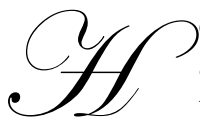

orizontal equity suggests that equals before tax should be equals after tax (Musgrave, 1959). In addition, an equitable or fair income tax is generally accepted as one that results in the "equal treatment of equals and the reasonable differences in the treatment of unequals" (Goode 1964, p. 11). For example, two households each making $\$ 20,000$ per year should pay an equal amount of tax. On the other hand, and over many years of tweaking tax policy, the US government has sought to encourage certain types of activities (having children, encouraging homeownership), the effect of which has been to reduce some level of horizontal equity. 
This study first shows that the elimination of two government-permitted deductions (the home mortgage interest deduction and the charitable contribution deduction) that encourage economic behavior increases horizontal equity.

The second point of this study is to demonstrate the decreases in horizontal equity due to the increases in phase outs. The effect of phase outs is to create even more disparity between taxpayers with similar (even very similar income) by encouraging certain activities - activities (paying college tuition, having more children) that some taxpayers can do and others cannot (either for purely "situational" reasons - they do not have a child attending college, or for "cash flow" reasons - they simply do not have enough excess cash to engage in such activities).

Phase outs have increased dramatically since 1986, particularly after the Bush tax increase in 1991 and continued to increase through the Clinton, G.W. Bush and already into the Obama administrations. In the 2006 tax year, it was estimated that $44 \%$ of all individual tax returns (around 60 million) were affected by at least one phase out (Herman, 2007).

Researchers have also begun to document the effects of the increases on horizontal equity, and in general have seen horizontal equity decline as the phase outs increase. For example, Gravelle and Gravelle (2006) found that there was dramatic effective tax rate differences among low income taxpayers with and without children due to the earned income credit, along with tax rates favoring high income taxpayers without children (since exemption amounts are phased out.) They also find that eliminating three phase outs (applied to itemized deductions, child credit and personal exemptions) increases horizontal equity. Burman and Weiner (2004) showed that the alternative minimum tax (AMT) actually increases horizontal equity between families with and without children (since the personal exemptions amounts must be added back in arriving at AMT income) and between residents of high-tax versus low-tax states (again since those amounts have to be added back).

In this study, instead of looking at the elimination of specific phase outs and its effects on horizontal equity, we examine horizontal equity within smaller and smaller income ranges, described as equal circumstance groups. We argue that as income levels become narrower and narrower, individual taxpayers' financial abilities to engage in economic activities encouraged by phase outs become much more similar.

The study demonstrates two results. First, eliminating itemized deductions such as charitable contributions and home mortgage interest increases horizontal equity. Second, creating smaller and smaller bands of income width increases horizontal equity as well.

The remainder of this paper is divided into four additional sections. In section two, we discuss some literature in the area of horizontal equity generally, and within income groups specifically. Section three discusses the hypotheses we examined and the research design. Section four presents the results and section five concludes.

\section{LITERATURE REVIEW}

The optimum level of vertical equity has been a controversial issue over the years. Horizontal equity, however, has been described as "the most universally accepted of all principles of tax policy" (White and White 1965, 225). The literature examining horizontal equity has been lengthy and pronounced. In general, researchers have found that decreasing the number of tax laws increases horizontal equity. This result is true whether the sample is one income group or several. In fact, researchers have not been vigilant on the use of income groupings, using a varying number with little or no justification. This study will address this issue by showing that increasing the number of income groups creates stronger horizontal equity.

White and White (1965) examined horizontal inequity arising from homeowners' understatement of income due to the mortgage interest deduction, the property tax deduction and the imputed net rental return on homeowner's equity. They found that reducing the ability to deduct expenses for homeownership decreased the coefficient of variation (and hence increased horizontal equity). 
Madeo and Madeo (1984) documented the effects of the minimum tax provisions on horizontal equity. Taxpayers were first categorized as either all taxpayers, taxpayers who benefited from the maximum tax, or as taxpayers who did not benefit from the maximum tax but had to pay some minimum tax. They found that as the minimum tax provisions decreased, horizontal equity within each of their groups (divided into five categories by adjusted gross income) increased.

Pierce (1989) studied the horizontal equity effects of proposed changes in the tax law regarding homeowner preference such as the mortgage interest deduction and the property tax deduction. Using 30 different categories of taxpayers, the author found that horizontal equity, as measured by the coefficient of variation, increases as deductions allowed decrease.

These studies agree on the premise that eliminating some tax deductions, or multiple levels of taxes, increases horizontal equity. The results of these studies diverge (or do not discuss) the outcome when the income groups in the study are increased.

Why is this important? If horizontal equity increases as the number of income groups increases, it means (in a pre-phase out tax law system) that horizontal equity was particularly strong among very similar income groups. Hence, introducing phase outs, where some in the narrowly defined income group can take advantage of the law (sometimes through planning, other times through mere happenstance) while other can not, will once again distort horizontal equity.

In the next section, we examine the tax law system in 1989, which is a system where nearly all phase outs enacted currently were yet to be implemented. We narrow the income range of each group by increasing the number of groups, and discover that horizontal equity increases merely on the basis of increasing the number of groups.

\section{HYPOTHESES AND RESEARCH DESIGN}

Equity study researchers routinely assume that changes in horizontal equity measures, which are induced by changes in tax laws, are not materially affected by the number of equal circumstance groups used in the analysis. This assumption is made in defending the generalizability of the study to other circumstances. Hence, if horizontal equity is present with using just one income group, horizontal equity will not increase if that number of groups is increase to ten, or twenty, or so on.

This study investigates the validity of this assumption using the horizontal equity measure, the coefficient of variation $(\mathrm{CV})$ and two hypothetical tax law changes, one disallowing the mortgage interest deduction and the other disallowing the charitable contributions deduction. To test the validity of this assumption, the following two hypotheses are proposed:

H1: The number of income groups used in the analysis has no effect on the weighted average change in the coefficient of variation when the mortgage interest deduction is disallowed.

H2: The number of income groups used in the analysis has no effect on the weighted average change in the coefficient of variation when the charitable contributions deduction is disallowed.

The Internal Revenue Service 1989 Tax File (ITF) for individuals (formerly known as the Tax Model File) and simulations of this data were used to examine the sensitivity of the equity measures to variations in the number of income groups. The ITF is a machine-readable data source including a stratified sample of 96,588 individual returns selected from a population of 112.2 million returns. For each return the Internal Revenue Service provides a corresponding weighting factor that indicates how many population returns the single sample return represents. Of the 96,588 sample of returns in the ITF, 59870 Form 1040 returns classified as married filing jointly for the calendar year 1989 were selected for this study. This study only used married filing jointly returns in to make the equal circumstance groups as homogeneous as possible. By incorporating the weighting factor in all the analyses, an estimated population of 47,200,861 married filing jointly returns were examined. 
Before horizontal equity can be measured, taxpayers must be classified into equal circumstance groups according to ability-to-pay. To operationalize ability-to-pay, adjusted expanded income ("AEI") as used by Ricketts (1990) and similar to expanded income used in numerous studies (Anderson (1985); Pierce (1989); Enis and Craig (1990); and Grasso and Frischmann (1992)), was the income measure incorporated in this study because it is a broader income measure that better approximates income. Therefore, for each sample return, AEI was calculated by adding to the taxpayer's AGI tax-exempt interest, allowable IRA, Keogh and SEP contribution deductions, allowed passive losses, nontaxable security benefits, nontaxable pensions, and tax preferences items (assumed to be passive activity related) in excess of the absolute value of losses allowed for passive activities. After calculating AEI for each taxpayer, the taxpayers were grouped from the least to the greatest AEI.

To explore whether a variation in the number of equal circumstance groups has an effect on the percentage change in the coefficient of variation, horizontal equity measures were calculated using the alternative number of groups shown in Table I (which compares one income group, versus two income groups, etc., to 26 income groups).

Table 1

Research Design Matrix

\begin{tabular}{|c|c|c|}
\hline Factor Studied & $\begin{array}{c}\text { Mortgage Interest } \\
\text { Deduction } \\
\text { Disallowed }\end{array}$ & $\begin{array}{c}\text { Charitable } \\
\text { Contributions } \\
\text { Deduction } \\
\text { Disallowed }\end{array}$ \\
\hline $\begin{array}{c}\text { Number } \\
\text { of Income Groups }\end{array}$ & $\begin{array}{l}\mathrm{G} 1, \mathrm{G} 2 \ldots, \\
\mathrm{G} 11\end{array}$ & $\begin{array}{c}\mathrm{G} 1, \mathrm{G} 2 \ldots, \\
\mathrm{G} 11\end{array}$ \\
\hline
\end{tabular}

$\mathrm{Gi}=$ Number of income groups simulations

$(\mathrm{G} 1=$ six; G2=eight; G3=ten...G11=twenty-six $)$

Prior horizontal equity studies have included income brackets ranging from five to twenty-eight, thus the alternative simulations in this study ranging from six to twenty six with equal numbers of taxpayers in each group is representative of the existing literature. Tax liabilities using a $20 \%$ proportional tax were recalculated, and each taxpayer's effective tax rate was determined for the pre-tax law change scenario. Two of the larger deductions used by married couples who file joint tax returns are the home mortgage interest deduction and the charitable contributions deduction. Each of these deductions was disallowed separately, and the tax liabilities were also recalculated and each taxpayer's effective tax rate determined for each of the post tax-law change scenarios. For each of these deductions and the corresponding simulations, horizontal equity was measured using the CV by allowing the deduction (pre-tax law change) and then by disallowing the deduction (post-tax law change).

\section{Coefficient of Variation}

In earlier studies the coefficient of variation was calculated by either using taxpayers' actual tax liabilities (White and White 1965; Anderson 1985; and Enis and Craig 1990) or effective tax rates (Pierce 1989; and Ricketts 1990). Pierce and Ricketts both note that by using effective tax rates comparability should be improved by lessening dispersion within a group that results from the range of incomes. The coefficient of variation formula used in this study is as follows (adapted from Ricketts 1990, 41):

$$
\mathrm{CV}_{\mathrm{j}}=\underset{\mathrm{ETR}_{\mathrm{j}}}{\mathrm{ETR}_{\mathrm{j}}} \times 100
$$

where:

$\mathrm{CV}_{\mathrm{j}} \quad=$ coefficient of variation for group $\mathrm{j}$

$\mathrm{SD}_{\mathrm{j}} \quad=$ the standard deviation of the effective tax rate for group $\mathrm{j}$

$\mathrm{ETR}_{\mathrm{j}} \quad=$ the mean effective tax rate for group $\mathrm{j}$ 


\section{Percentage Change in CV}

As discussed earlier, the coefficient of variation was tested for its sensitivity of variations in the number of income groups. Therefore, percentage changes in horizontal equity measures were computed for both tax law change scenarios under each alternative simulation (similar to Anderson 1985; Pierce 1989; and Ricketts 1990). The formula for the percentage change in the coefficient of variation is as follows:

$$
\mathrm{PCCV}_{\mathrm{i}}=\frac{\mathrm{CV}_{\text {pre }}-\mathrm{CV}_{\text {post }}}{\mathrm{CV}_{\text {pre }}} \times 100
$$

where:

$\mathrm{PCCV}_{\mathrm{i}}=$ Percentage change in the $\mathrm{CV}$ for income group $\mathrm{i}$

$\mathrm{CV}_{\text {pre }}=\mathrm{CV}$ for the pre-tax law change simulation

$\mathrm{CV}_{\text {post }}=\mathrm{CV}$ for the post-tax law change simulation

$\mathrm{i}=$ Number of income groups

A positive change indicates improved horizontal equity.

\section{Weighted Average Percentage Change in CV}

Next, the overall weighted average percentage change in the CV measures from the pre- to the post-law change for each of the number of income group alternative simulations. The equation is as follows:$$
\mathrm{WACV}=\frac{\Sigma\left(\mathrm{N}_{\mathrm{i}} \mathrm{x} P C C \mathrm{P}_{\mathrm{i}}\right)}{\Sigma \mathrm{N}_{\mathrm{j}}}
$$

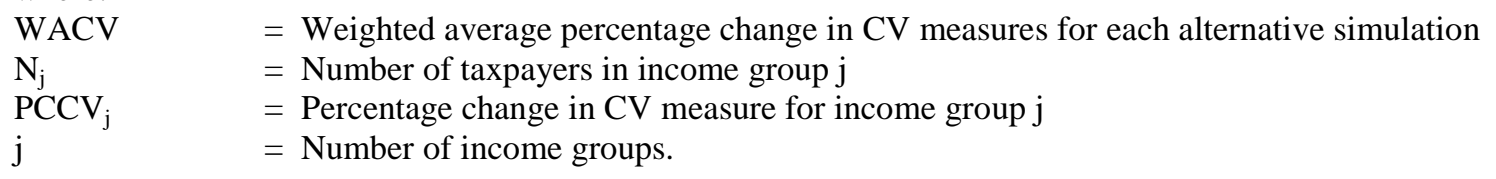

$$
\begin{aligned}
& \text { where: } \\
& \text { WACV } \\
& \mathrm{N}_{\mathrm{j}} \\
& \mathrm{PCCV}_{\mathrm{j}} \\
& \mathrm{j}
\end{aligned}
$$

Since there were eleven simulations, there were eleven WACV for each of the two hypothetical tax law changes. To test the hypotheses, WACV measures were tested for a trend using the Cox and Stuart Trend test (Conover 1971).

\section{RESULTS}

\section{Coefficient of Variation Pre- and Post-Tax Law Change}

By comparing the pre-tax law change $\mathrm{CV}$ to the post-tax law change $\mathrm{CV}$ for the individual income AEI groups, it can be observed that in each case the post-tax law change CV is always less than the pre-tax law change $\mathrm{CV}$. A decrease in the CV represents an increase in horizontal equity. Thus, for all number of groups alternatives, the disallowance of the mortgage interest deduction and, alternatively, the charitable contributions deduction resulted in an improvement in horizontal equity.

\section{Sensitivity Analysis}

To measure the improvement in horizontal equity, the percentage change in the CV (PCCV) for each hypothetical law change was calculated. A positive percentage change in the CV indicates an improvement in horizontal equity while a negative percentage change indicates a decline in horizontal equity. Consistently, the PCCV was positive for all the alternative simulations. Therefore, disallowance of either the mortgage interest deduction or the charitable contributions deduction resulted in improved horizontal equity for all income groups.

Finally, an overall weighted average of the percentage change in the CV (WACV) was calculated for each alternative simulation of the number of income groups. As the number of income groups increased, there was a gradual increase in the WACV. 
These overall WACV were then used to conduct the Cox and Stuart test for trend. Table 2 shows the application of the trend test for the CV. For both post-tax law change scenarios, therefore, H1, the hypothesis that the number of groups does not have an effect on the resulting WACV is rejected. Furthermore, $\mathrm{H} 2$, the hypothesis that the number of income groups does not have an effect on the resulting WACV, is also rejected. However, while there is a statistically significant trend in the WACV as the number of groups increase, one may argue it does not result in a material difference. For example, with regard to the mortgage interest tax law change, the difference between the WWACV for the G1 simulation (using 6 income groups) and the WACV for the G11 simulation (using twenty-six income groups) is only .56 percent. Furthermore, the difference between the WACV for the G1 and the G11 charitable contributions simulation is an even smaller difference of .13 percent.

Table 2

H1 and H2 Trend Test

\begin{tabular}{|c|c|c|}
\hline Number of Groups Paired Simulations & $\begin{array}{c}\text { WACV } \\
\text { Mortgage Interest }\end{array}$ & $\begin{array}{c}\text { WACV } \\
\text { Charitable }\end{array}$ \\
\hline$(\mathrm{G} 1, \mathrm{G} 7)$ & $(10.00,10.49)+$ & $(2.69,2.81)+$ \\
\hline$(\mathrm{G} 2, \mathrm{G} 8)$ & $(10.18,10.51)+$ & $(2.73,2.81)+$ \\
\hline$(\mathrm{G} 3, \mathrm{G} 9)$ & $(10.30,10.52)+$ & $(2.76,2.81)+$ \\
\hline$(\mathrm{G} 4, \mathrm{G} 10)$ & $(10.41,10.56)+$ & $(2.79,2.82)+$ \\
\hline$(\mathrm{G} 5, \mathrm{G} 11)$ & $(10.44,10.56)+$ & $\mathrm{T}=5$ \\
\hline
\end{tabular}

\section{CONCLUSIONS}

This study begins by examining the changes in horizontal equity (as measured by the coefficient of variation). Using the Internal Revenue Service Tax File database for roughly 60,000 married filing joint returns, we examined the sensitivity of equity measures to two "artificial" changes in the tax laws - the disallowance of the mortgage interest deduction and the charitable contribution deduction. Not surprising, we found the disallowance of either or both deductions increases horizontal equity.

Additionally, in the absence of phase outs (using the 1989 IRS tax file), we proved that as income groups become more numerous (and hence narrower bands of income), horizontal equity increases as well. This outcome is at odds with prior tax equity studies that make the assumption that the increasing or decreasing of the number of equal circumstance groups (taxpayers with similar income) will have no substantive effect on the outcome of horizontal equity measures.

This study has important implications in two respects. First, from a methodological standpoint, prior studies should have strengthened their assumption on the number of equal income groups used. Second, from a public policy perspective, continuing to increase the number of phase outs within the tax system further distorts horizontal equity.

This study does not look directly at the differences in a tax year with dozens of phase outs (like 2008) and compare it with 1989 (the IRS files were no longer published after 1992). A future study which could overcome that lack of data and examine such changes could strengthen the results of this study.

\section{AUTHOR INFORMATION}

Susan K. Rhame, PhD, CPA is an affiliate professor of accounting at the University of Dallas. She holds degrees from Mississippi State University, Louisiana State University, and the University of Texas at Arlington (UTA). Prior to attending UTA to pursue her doctorate she worked in the tax department at Arthur Young in Dallas, Texas.

Robert J. Walsh, $\mathrm{PhD}$ is an associate professor of accounting at the University of Dallas, College of Business. He holds a PhD, MBA, MS and BBA from the University of Notre Dame. He previously has taught at Marist College, where he also served as department chair and interim dean. Prior to entering academia, he was employed in the 
audit department of Deloitte, Haskins and Sells and the tax department of Coopers and Lybrand, both in Detroit, Michigan.

\section{ACKNOWLEDGEMENT}

A version of this paper was presented at the 2009 International Applied Business Research Conference in

San Antonio, Texas. The authors wish to thank workshop participants for their comments. Any remaining errors or omissions remain solely the responsibility of the authors.

\section{REFERENCES}

1. Anderson, K.E. 1985. A Horizontal Equity Analysis of the Minimum Tax Provisions. The Accounting Review. 60 (3): 357-371.

2. Burman, and Weiner. 2004. Suppose They Took The AM out of AMT? Proceedings of the 2004 National Tax Association - Tax Institute of America -Annual Meeting. 447-458.

3. Conover, W.J. 1971. Practical Nonparametric Statistics. New York: John Wiley \& Sons Inc.

4. Copp, C. and McGill, G. 2005. Visibility and Perception of Fairness: Now you see it, now you don't tax policy of the 1990s? Tax Notes. 1013-1016.

5. Enis, C.R. and D.L. Craig. 1990. An Empirical Analysis of Equity and Efficiency Attributes of Regressive Forms of a Flat Tax. The Journal of the American Tax Association. (Spring): 17-33.

6. Goode, R. 1964. The Individual Income Tax. The Brookings Institute.

7. Grasso, L.P. and Frischmann, P.J. 1992. Measuring Horizontal Equity: A Regression Approach. The Journal of the American Taxation Association. (Fall): 123-133.

8. Harmelink, P. and Copeland, P. 2004. Hidden Taxes Through Phase Out and Floors: Assessment and Policy Implications. Tax Notes. 78-84.

9. Gravelle, J. and Gravelle, J. 2006. Fair Taxation of Families: Old Law or New Rules? Tax Notes. 14071408.

10. Gravelle, J. and Gravelle, J. 2006. Horizontal Equity and Family Tax Treatment: The Orphan Child of Tax Policy. National Tax Journal. 59 (3): 631-649.

11. Herman, T. 2007. The Tax Hit You May Not See. The Wall Street Journal. January 10.

12. Madeo, S. and Madeo, L.A. 1984. The Equity and Motivating Effects of the Maximum Tax. The Journal of the American Taxation Association. (Spring): 40-49.

13. Musgrave, R. 1959. The Theory of Public Finance. New York, NY: Mc-Graw Hill.

14. Pierce, B.J. 1989. Homeowner Preferences: The Equity and Revenue Effects of Proposed Changes in the Status Quo. The Journal of the American Taxation Association. (Spring): 54-67.

15. Ricketts, R.C. 1990. Social Security Growth Versus Income Tax Reform: An Analysis of Progressivity and Horizontal Equity in the Federal Tax System in the 1980's. The Journal of the American Taxation Association. (Spring): 34-50.

16. Steuerle, C. 2001. The Simple Case for Tax Simplification. Tax Notes. 1497-1501.

17. Tandon, C. 2006. Tax Benefits Fail from Horizontal Equity Perspective. Tax Notes. 1002.

18. Westort, P. and Wagner, J. 2002. Toward a Better Measure of Horizontal Equity. The Journal of the American Taxation Association. 24.1. 17-28.

19. White, M. and A. White. 1965. Horizontal Inequality and the Federal Tax Treatment of Homeowners and Tenants. National Tax Journal. 18 (3): 225-239. 


\section{NOTES}

